\title{
An Approach for Dairy Buffalo Development through Investment in Genetic Improvement
}

\author{
Ibrahim Soliman ${ }^{1, *}$ and Basher Bahgat ${ }^{2}$ \\ ${ }^{1}$ Professor of Agricultural Economics, Faculty of Agriculture, Zagazig University, Egypt \\ ${ }^{2}$ Agricultural Economist, Zagazig University, Zagazig, Egypt
}

\begin{abstract}
Dairy products are an essential source of animal protein, particularly for nutritional vulnerable groups and vegetarians in Asian countries. Therefore, the approach towards increasing the domestic supply of milk is to raise the buffalo milk yield via genetic improvement from the semen of the selected buffalo sire that possesses a high predicted milk difference. Data were collected from Artificial Insemination Centers in Egypt, as a case study, to apply a dynamic mathematical investment model for estimating the rate of return (IRR) to genetic investment. The effective variables in IRR, besides the economic variables, are the reproductive traits and feed efficiency. The estimated most probable level of IRR was feasible, i.e., $19.71 \%$. A worse change in the reproductive efficiency variables, i.e., the aggregate of $10 \%$ increase in the number of conception services, age at the First Calving, and the service period, would decrease the IRR by $7.51 \%$. A decrease in feed efficiency by $10 \%$ would decrease the IRR by $9 \%$. A worse change by $10 \%$ in the feed costs, price of semen, and milk price would decrease IRR by $7 \%$. To import buffalo sires' semen of high predicted milk difference at moderate prices till establishment, domestic genetic merit is required.
\end{abstract}

Keywords: Dairy buffalo, Feeds, Genetic improving, Investment model, Reproductive traits.

\section{INTRODUCTION}

Egypt has a comparative advantage in milk production from the domestic dairy buffalo, rather than red meat production [1]. Therefore, the feasible development plan is essential to give priority for increasing the domestic milk supply rather than red meat production from Egyptian buffalo, particularly that importing fresh milk and/or dairy products is highly expensive because they are very perishable food commodities [2]. The importance of increasing the domestic production of milk in Egypt via genetic improvement stems from the lack of sufficient resources for horizontal expansion in livestock population due to the limited feeds production, water, and agricultural land resources constraints [3]

Egypt has almost no natural rangeland, which creates issues in high competition between grain crops and green foods on limited irrigation water and agricultural land to satisfy the demand for human food and livestock feed, respectively [4]. The main livestock feed is the Egyptian clover (Berseem), which is a winter season crop (Oct-May) that competes with wheat on agricultural resources [5]. Cultivated berseem area determines the milking head numbers, the calf crop, and the milk supply [6]. Therefore, the increase in dairy heads beyond the carrying capacity goes as offtake for slaughter [7].

*Address correspondence to this author at the Professor of Agricultural Economics, Faculty of Agriculture, Zagazig University, Egypt; Tel: +201205026060, +201227783157; E-mail: ibsoliman@hotmail.com
Due to before mentioned constraints, expansion in livestock dairy heads would not be economical to cover the increasing deficit between milk production and the effective demand [7]. Accordingly, the only possible approach for livestock development in Egypt is to fix the livestock size within the carrying capacity of the food availability allowance, focusing on the vertical expansion by increasing the milk yield per milking buffalo head [8], significantly. Such vertical expansion should be approached via genetic improvement of the domestic buffalo population using Artificial Insemination (Al) with the semen of selected buffalo sires [9]

The accumulation of costs and returns of genetic improvement over time and actualize the different strategies over different periods, should be expressed in comparable time units due to differential expression of improvement from a selection over time [10]. Discounting is the usual method of comparison for which revenue streams and future costs are transformed into existing values. Financial and economical are the two types of cost-benefit analysis [11]. The financial examination is the evaluation of a project's feasibility from the perception of agencies or individuals. The welfare of the nation at a core is considered for economic analysis. Financial analyses might be appropriate for Egypt as the breeding industry is often controlled privately [12].

In this regard, the study has designed and implemented a mathematical model to estimate the internal rate of return (IRR) along with the full productive life of the daughter of the dairy buffalo using 
the $\mathrm{Al}$ of the concerned sire's semen. The study estimated the most likely IRR at the average performance of the buffalo reproductive traits and the significant economic variables. After that, it estimated the impacts of unfavorable economic conditions, and less efficient reproductive traits, i.e., older age at first calving, more numbers of Al services required for conception, and a more extended service period leading to a longer calving interval, as well as the less feed efficiency.

To determine the return to investment of genetic improvement, the ordinary cash flow statement does not fit because livestock is a dynamic investment model of production, not an ordinary investment type. It is characterized by the depreciation of assets and treated via a systematic annual cash flow of benefits and costs. It needs a special financial mathematical model. The time horizon of such a model is determined by the inseminated dairy buffalo's production cycle and the five successive lactation seasons of its daughter. While the investment cost is determined by the semen dose price and the Number of conception services [13], the life cycle of such an investment is determined by the reproductive criteria.

The major reproductive criteria include age at first calving and the calving interval. As the gestation period is constant, the service period length determines the calving interval. On the other hand, the milk yield level and persistency period require adjustment for cow age and milking season order [14]. Feed efficiency is also an essential techno-economic variable that affects milk productivity and profitability as it represents the highest proportion of the operation costs of dairy cattle farms [15]. Most textbooks on feasibility studies of agricultural projects avoided such dynamic models [16-19]. Even the previous studies which applied assessment of the sire's predicted difference restricted the analysis for comparison among sires in terms of the net present value (NPV) of the first calving of the daughter because the authors were interested only in finding an index for sire's selection [20, 21].

\section{MATERIALS AND METHODS}

The use of artificial insemination technology (Al) in Egyptian agriculture is very limited, whether with the traditional or specialized herds, and there is a lack of reproductive or even productive records in most farms [22]. Therefore, the study sample was restricted to the data of the records of the specialized research centers, where artificial insemination records can be obtained. Therefore, it is a purposive non-probabilistic sample.
As the number of artificial insemination centers is very limited in Egypt, the sample included the records of one of the largest Buffalo Research Stations in the Gharbia Governorate, which is in the middle of the Nile Delta region. It is managed by the Ministry of Agriculture and Land Reclamation.

Such a purposive sample provided various privileges. Firstly, the Centre's management understood the nature and importance of the study and thus, facilitated access to the required data. Secondly, the availability of records was for two herds at the station, one set was a flock of naturally inseminated dairy buffaloes with the semen of unselected bull (18 heads), and the second a herd of daughters of buffalo dams artificially inseminated by the semen of selected buffalo sires ( 15 heads). The records of the first herd (18 heads) of dairy buffaloes were used to get the dairy buffalo's average productive and reproductive performance variables without genetic improvement. The second herd included the daughters (15 heads) of dams under the Al program of the improved sire's semen. The second herd records were used to get the average milk yield of the genetically improved daughters.

The average of productive and reproductive traits estimated from the records of the genetically unimproved sample is presented in Table 1. The milk yields over successive milk seasons of the genetically unimproved herd were used to calculate the Mature Equivalent Factor (MEF), as shown in Table 2. The MEF index was used to adjust the milk yield resulting from the estimated Predicted Milk Difference (PMD) to represent the improved milk yield of daughters over five successive seasons [23]. The second sample data were used to estimate the average milk yield per season of the daughters of the dairy buffalo dams inseminated artificially by the semen of selected buffalo sires raised in the artificial insemination center (Table 2). This sample was also used to estimate the PMD as the criteria of probable improvement in the milk yield of the Egyptian buffalo population in Egypt. When determining PMD, the population average of the daughters' milk yield was compared with the average milk yield of the genetically unimproved dairy buffalo herd.

The classical investment analysis model calculates the discounted net benefit derived from the cash flow as a stream of both annual inflows (costs) and outflows (benefits). However, it does not fit the purpose of the 
genetic investment analysis. The livestock investment model was affected by the changes in the reproductive cycle. Such a cycle comprises a set of variables that were measured in days and months and not on a full year base. These reproductive performance traits were mainly the age at the $1^{\text {st }}$ calving, the service period (the period between calving and the successive conception of the dam), the calving interval (the sum of the gestation period and service period), and the Number of services required for conception and the mortality rate. Therefore, the IRR estimation (the discount rate that maximizes the return to investment) would be affected by nonsystematic periods measured in months. In addition, the outflows (revenues or benefits) are generated from the probable increase in milk yield of the daughters of the inseminated dam from the concerned breeding sire.

The sire is supposed to transfer what is called the "Predicted Selection Difference" of the milk of the semen, i.e., "PMD". It represents the potential quantity of milk, which is added to the average yield of his daughters. The investment costs in this study were the price of the units of Al from a certain sire's semen. The level of such a price was associated with the level of PMD. The feed costs were the bulk of the operating costs [24]. The feed cost was mainly a function of the feed conversion rate, which, in turn, was the most vital productive trait that affects the return to investment [25]. The incremental net benefit's model considered only the feed costs as the main variable costs' item, which directly affects the changes in milk yield.

\section{The Model's Assumptions}

(1) The investment period expanded to 10 years, to allow for the genetic investment to give its full potentiality over five successive milking seasons of the daughter of the served dairy buffalo by the selected sire.

(2) The average age at the first calving estimated from the field survey data.

(3) As a conservative evaluation, it was assumed that the first replacement heifer of the offspring comes from the second calving of the served dairy buffalo.

(4) To avoid the exact date of the conception, when the cost of the inseminated semen was allocated, it was assumed to be at the onset of each calving interval.
(5) The gross margin above the feed costs introduced in the model was a ratio from the total income (incremental income above feed costs).

(6) As the model focuses on genetic improvement of the milk yield, thereby the income generated from the calves' crop is neglected.

(7) The minimum nominal interest rate was the financial average discount rate in the financial market of Egypt in 2017.

(8) Such an interest rate was used as a standard to compare it with the rate of investment generated from the genetic improvement of the dairy buffalo. Therefore, the estimated IRR is considered feasible if it passes the standard interest rate and is above the inflation rate in milk price.

(9) The base period is the time of introducing the first semen service.

(10) The discounted net present value should be calculated on a monthly base rather than a yearly basis.

\section{Analytical Procedures}

The analytical procedure was presented in a comprehensive approach via six sections: estimating PMD, the model's hypothesis, the model's equations, the definition of the model's variables, and the model's assumptions.

\section{Estimation of the Predicted Milk Difference}

The PMD was the probable increase in milk yield above the herd average transmitted from the semen of selected sire via the artificially inseminated dairy buffalo to its daughters. The PMD in this study was estimated from the model of Equation 1:

$$
P M D=\left(M Y_{d}-M Y_{h}\right) *\left(h^{2}\right)
$$

where:

PMD = Predicted Milk Difference supposed to be transmitted to the daughter via the inseminated dam from the selected buffalo sire,

$M Y_{d}=$ the average milk yield per daughter per season,

$M Y_{h}=$ the average milk yield per season of the target buffalo herd, and 
$h^{2}=$ heritability coefficient of buffalo milk [26]

It should be mentioned that the mathematical model was presented in this study for assessing the feasibility of the Al program for genetic improvement of the milk yield of the domestic dairy buffalo. However, it was recommended for other dairy livestock types (cattle, sheep, or goats) by introducing the correspondent technical coefficients of each type. In addition, it is valid not only for assessment of the genetic assessment of milk yield, but it is also applicable for other traits of milk quality, particularly milk fat and milk protein contents, which could be added to the model when such quality criteria have significant impacts on milk demand and price. If such traits were added, weights should be associated with each trait generated income to reflect the national strategy towards investment in genetic improvement for milk production.

\section{The Mathematical Model's Equations}

The model composed by the authors simulated the classical investment statement or the cash flow statement of the projects' appraisal [19], but it was adapted to fit the study's objectives. Therefore, it comprised of 17 equations, as follows:

$$
\begin{aligned}
& N P V=n P_{1}-n P_{2}(1+i)^{-a}-n P_{3}(1+i)^{-b}-I_{1}(1+i)^{-c} \\
& \quad+I_{2}(1+i)^{-d}+I_{3}(1+i)^{-e}+I_{4}(1+i)^{-f}+I_{5}(1+i)^{-g} \\
& I=r_{c}-r_{p}
\end{aligned}
$$

where

$r_{c}=$ interest rate in the Egyptian financial market

$r_{p}=$ inflation rate of producer milk price

$\Sigma N P V=$ Zero $\sim i=I R R$

where

NPV $=$ Net present value

$n=100 / A C R$

where

$\mathrm{n}=$ Average number of semen units/calving interval, for" $k$ " intervals, where $k=1,2,3,4,5$

$$
A C R=C R\left(1-\% \frac{M R}{100}\right)
$$

where
$\mathrm{ACR}=$ Adjusted conception rate $(\%)$

$\mathrm{CR}=$ Conception rate from the $1^{\text {st }}$ service $(\%)$

MR = Mortality rate of dairy buffalo (\%)

$I_{k}=M_{k}(I-R)$

where

$I_{\mathrm{k}}=$ Incremental milk income above feed costs at calving interval $k$, in (EGP)

$M_{k}=P_{m}\left(\frac{P M D}{M E F_{k}}\right) *(M D)$

where

$\mathrm{M}_{\mathrm{k}}=$ Incremental milk income at calving interval $\mathrm{k}$, in (EGP).

PMD = predicted selection difference for daily milk yield $(\mathrm{Kg})$ for the concerned breeding sire.

$P_{m}=$ average price/ 1-kg of milk at the base year (EGP)

$R=\left(M_{k}-F C\right) / M_{k}$

where

$\mathrm{M}_{\mathrm{k}}=$ Incremental milk income at calving interval $\mathrm{k}$, in (EGP).

$\mathrm{R}=$ proportion of feed costs in gross milk income from a daughter of the breeding sire.

$C I=G P+S P$

where

$\mathrm{SP}=$ service period

$\mathrm{GP}=$ gestation period

$a=A G C$

$b=a+C I$

$c=b+A G C+0.5 L P$

$d=c+C I$

$e=d+C I$

$f=c+C I$

$g=f+C I$ 
Table 1: Estimated Averages of Major Traits of the Inseminated Dairy Buffalo Herd

\begin{tabular}{|c|c|}
\hline Productive and Reproductive Traits & Average \\
\hline \hline Average Number of Services for Conception & 2.00 \\
\hline Average Adjusted Conception Rate from 1st service (\%) & $50 \%$ \\
\hline Age at 1st calving (month) & 32.50 \\
\hline Average daily milk yield (Kg) & 7.6 \\
\hline Average lactation period per season (day) & 1781.5 \\
\hline Average Milk Yield per season (Kg) & 450 \\
\hline Average Carving Interval (Month) & 135 \\
\hline Average Service period & 3.15 \\
\hline Average feed costs per Kg milk (EGP) & $69 \%$ \\
\hline
\end{tabular}

Source: Compiled and calculated per 1-dairy buffalo from the inseminated buffalo herd in the Al Center; except the last row, which comes from the records of the genetically improved daughters *EGP $=($ Egyptian pound); 1 -US $\$=17.60$ EGP in 2017.

Where:

$A G C=$ age at first calving

$\mathrm{Cl}=$ calving interval

\section{RESULTS AND DISCUSSION}

The average reproductive performances of the domestic dairy buffalo were presented in Table 1. The average age at first calving was around 32.5 months; the service period was 135 days, and the calving interval reached 450 days. The required Number of services for conception was around 2.0. However, the effects of the order of lactation seasons of the dairy buffalo on milk production have been taken into consideration via correction for the MEM of dairy buffalo, as shown in Table 2. Accordingly, the PMD in the $\mathrm{k}$ lactation season was adjusted for the predicted milk yield per season over five successive seasons using the corresponding MEM index. The mature calving season is the $3^{\text {rd }}$ season, where the PMD would

Table 2: Estimation of the Mature Equivalent Index of Milk Yield/ Season (MEM)

\begin{tabular}{|c|c|}
\hline Lactation Season & Mature Equivalent Factor \\
\hline \hline 1st Lactation & 1.4 \\
\hline 2nd Lactation & 1.2 \\
\hline 3rd Lactation & 1. \\
\hline 4th lactation & 1.1 \\
\hline 5th lactation & 1.1 \\
\hline $\begin{array}{c}\text { Average milk/season/ dairy dam } \\
(\mathrm{Kg})\end{array}$ & 1781.5 \\
\hline
\end{tabular}

Source: Compiled and calculated from.

(1) Van Tassell, et al., 1995.

(2) The inseminated buffalo herd in the Al Center. reach its full performance, i.e., MEM equals one, and then there would be a slow decrease in the milk yield of the daughter in the 4 th and the $5^{\text {th }}$ season.

Therefore, the increase in the daughter milk yield would reach its full potential incremental increase ( $P M D=425 \mathrm{~kg}$ milk/day) as derived from Equation 1 in the $3^{\text {rd }}$ season. Such an amount multiplied by the Number of milking days would be fully added to the average milk yield per cow of the herd, and a lesser amount of milk would be added to the other seasons.

\section{Internal Rate of Return}

IRR is the discount rate, which made the sum of the NPV equal to zero at the most probable levels of the performance profile. As shown in Table 3, IRR was estimated as $19.71 \%$. It is much higher than both the annual inflation rate in milk price $(10.5 \%)$, and the average discount rate in the financial market in 2017 was $16.0 \%$ [27] Therefore, the genetic improvement in domestic dairy buffalo was significantly feasible. The Number of domestic milking buffaloes in Egypt was around 1.769 million heads in 2015 [28]. Therefore, an expected additional increase in domestic milk supply per year due to genetic investment would be around 751,981 tons.

Such an incremental quantity would reach around $13.5 \%$ of the existing milk production of Egypt, which reached 5.551 million tons in the same year. However, such a predicted increase in milk production covers around $64.4 \%$ of imported fresh dairy products, estimated as milk equivalent [28]. If buffalo milk were estimated as $4 \%$ fat milk equivalent, rather than $7.8 \%$, using Jean's equation [29], the expected increase in milk yield would represent about $23 \%$ of total milk 
Table 3: Average Economic and Reproductive Variables of the Investment Model

\begin{tabular}{|c|c|c|}
\hline The Model's Variables & Symbols & Average \\
\hline \multicolumn{3}{|l|}{ Economic Variables } \\
\hline Farm Gate Price of Milk (EGP) & $P_{m}$ & 5.00 \\
\hline Average discount rate in the financial market in 2017 (\%) & $r_{c}$ & $16 \%$ \\
\hline Annual Inflation rate of producer Price of milk (\%) & $r_{f}$ & $10.50 \%$ \\
\hline Average Monthly discount rate (\%) & & $1.33 \%$ \\
\hline Semen Price per unit (EGP) & $P_{s}$ & 50 \\
\hline Proportion of milk Cost in Total Revenue (\%) & $\mathrm{R}$ & $69 \%$ \\
\hline \multicolumn{3}{|l|}{ Technical Variables } \\
\hline Expected Selection Difference of the semen $(\mathrm{Kg})^{*}$ & PDM & 425.00 \\
\hline Average Number of services for conception & ACR & 2.00 \\
\hline Adjusted Conception rate from $1^{\text {st }}$ Service (\%) & $\mathrm{CR}$ & $50.00 \%$ \\
\hline Mortality rate of Dairy Cows & MR & $1.2 \%$ \\
\hline Age at the First Calving & AGC & 32.5 \\
\hline Calving Interval & $\mathrm{Cl}$ & 450 \\
\hline Service Period & SP & 135 \\
\hline
\end{tabular}

Source: compiled from Table 1; *Estimated from (Equation 1) using data of Table 1.

production and $109 \%$ of imported milk equivalent of dairy products.

\section{Sensitivity Analysis of the IRR towards Undesirable Conditions}

The predicted changes in the IRR due to probable deterioration in reproductive and productive performances of the domestic buffalo were estimated as presented in Table 4. A 10\% increase in the Number of services for conception, age at first calving and service period would aggregately decrease the IRR by $7.5 \%$ to be around $12.2 \%$, i.e., the IRR on the genetic investment would not be feasible as it became less than the interest rate on livestock loans. An increase in feed costs by $10 \%$ would drop the IRR by $9 \%$ to reach about $11 \%$, which almost covers the annual inflation in milk prices, without any positive net benefit to entrepreneurs. Such an increase in feed costs could be due to either an increase in feed prices or a decrease in feed efficiency.

Unfavorable changes in the economic variables, i.e., a $10 \%$ increase in semen dose price and milk price, would be around $7 \%$. It is of less drastic negative impact on IRR than a similar change in reproductive traits or feeds efficiency, i.e., to reach around $13 \%$.

Table 4: Estimation of Most Probable IRR and Sensitivity Analysis

\begin{tabular}{|c|c|c|c|}
\hline Model's Critical Variables & Expected Change & Estimated IRR & Change in IRR \\
\hline \hline Most Probable IRR & No change & $19.71 \%$ & $0.00 \%$ \\
\hline Milk Price & $10 \%$ less & $15.98 \%$ & $-3.73 \%$ \\
\hline Semen Unit Price & $10 \%$ more & $16.67 \%$ & $-3.05 \%$ \\
\hline All Economic Variables & & $12.67 \%$ & $-6.98 \%$ \\
\hline Number of services for Conception & $10 \%$ more & $16.26 \%$ & $-3.38 \%$ \\
\hline Age at the First Calving & $10 \%$ more & $16.15 \%$ & $-0.62 \%$ \\
\hline Service Period & $10 \%$ more & $19.09 \%$ & $7.50 \%$ \\
\hline All Reproductive Traits & $10 \%$ more & $10.85 \%$ & $-5.65 \%$ \\
\hline Feed Efficiency & $10 \%$ more & $14.06 \%$ & \\
\hline
\end{tabular}

Source: Calculated from the Investment Model using Tables $\mathbf{1}$ and $\mathbf{2}$ 
Therefore, a national research work supported by an effective extension program should be implemented to improve the reproductive traits and feed efficiency of the buffalo population.

\section{Policy Implications}

A $10 \%$ increase in the feed conversion rate decreases the return to investment of the genetic improvement of dairy buffalo by $9 \%$. A $10 \%$ increase in the Number of services for conception, service period and age at first calving would also decrease such a return to investment by another $7.5 \%$. Therefore, to assure a feasible return to investment in such a program, some supporting policies are required.

Among those policies is a training program for the inseminators and dairy buffalo holders on precise heat detection on time and proper application of Al. Such a program would help in decreasing the Number of services required for conception and consequently, the calving interval, which raises the return to investment. A supporting program should be associated with it. Such program objectives are a sufficient communication system for calling the inseminators on time, and the availability of sufficient transportation means in the villages, such as motorcycles.

A proper feeding system for replacement heifers would enable them to reach an appropriate weight earlier for breeding at a younger age for first calving. A credit line of soft loans should be provided to veterinary and agriculture college graduates to establish $\mathrm{Al}$ stations, and large investors to establish Al centers that produce liquid nitrogen and prepare the semen dose containers.

The main method of genetic improvement of buffaloes in Egypt was the importation of buffalo sire's semen. These were the tactics of choice due to the inadequate development of local breeding infrastructure. However, local progeny might be an economically suitable option for Egypt and can be an effective alternative with restricted foreign currency. Therefore, an economic assessment of a series of alternatives is required with a range of strategies and methods that might be beneficial to develop effective breeding policies for buffaloes, not only in Egypt but also in Asian countries.

The dairy breeding industry will consequently benefit from the major investment in genetic improvement research that is presently underway.
Genetic improvement programs would be embraced by large dairy producers and will consequently provide a sound investment market. The unemployment would be reduced due to the consolidation of the artificial insemination network and other dairy industries, where, currently, the investments in the dairy sector Egypt, by private and public institutions are inappropriate.

\section{ACKNOWLEDGEMENT}

The authors are very thankful to all the associated personnel in any reference that contributed to/for this research.

\section{REFERENCES}

[1] Soliman I. Role of dairy buffalo in Egypt food security, Buffalo Newsletter, Bulletin of The FAO Inter-Regional Cooperative Research Network on Buffalo and of the International Buffalo Federation 2008; Number 23 - June.

[2] Soliman I, Bassiony H. Egyptian agricultural exports competitiveness L'Egpte contemportaine, Société egyptienne d'Economie Politique de Statistique et de Législation 2012; No. (505): 210-229.

[3] El Mowafy AE. Techno-Economics Assessment of Genetic Improvement via Artificial Insemination in Dairy Cattle in Dakahlia Governorate. Trends in Agricultural Economics 2015; 8(21): 21-27.

https://doi.org/10.3923/tae.2015.21.27

[4] Safwat M, Soliman I, Amer J, Fouad S. The Impacts of Economic Reform Policies on Wheat and Egyptian Clover. Zagazig Journal of Agricultural Research 2015; 42: 397-404.

[5] Aboelgoud SA, Mersal IF, Haggag MEM. Effect of potassium fertilizer rates and some plant extracts on forage, seed yield, and seed quality of Egyptian berseem under saline soil conditions. Journal of Plant Production 2015; 6: 1183-1198. https://doi.org/10.21608/jpp.2015.51222

[6] Radwan MAA. Characterization of milk and veal production chains of buffalo under crop-livestock production system in Egypt, Doctoral dissertation, Faculty of Agriculture, Cairo University 2016.

[7] Soliman I. Role of dairy buffalo in Egypt food security, Buffalo Newsletter, Bulletin of The FAO Inter-Regional Cooperative Research Network on Buffalo and of the International Buffalo Federation 2008; Number 23 - June.

[7] Soliman I. Economic feed utilization for dairy buffalo under the intensive agricultural system. Italian Journal of Animal Science 2007; 6: 1367-1375. https://doi.org/10.4081/ijas.2007.s2.1367

[8] Warriach HM, McGill DM, Bush RD, Wynn PC, Chohan KR. A review of recent developments in buffalo reproduction-a review. Asian-Australasian Journal of Animal Sciences 2015; 28: 451-460. https://doi.org/10.5713/ajas.14.0259

[9] De Vries A. Economic trade-offs between genetic improvement and longevity in dairy cattle. Journal of Dairy Science 2017; 100: 4184-4192. https://doi.org/10.3168/jds.2016-11847

[10] Kadarmideen HN, Mazzoni G, Watanabe YF, Strøbech L, Baruselli PS, Meirelles FV, Nogueira MFG. Genomic selection of in vitro produced and somatic cell nuclear transfer embryos for rapid genetic improvement in cattle production. Animal Reproduction (AR) 2018; 12: 389-396. 
[11] Pangmao S, Thomson PC, Khatkar MS. Dairy cattle industry and genetic improvement programs in Thailand. Animal Production Science 2017; 57: 1242-1247. https://doi.org/10.1071/AN16454

[12] Soliman I. The economic feasibility of artificial insemination methods in genetic investment programs. In Proceedings of the Seminar on Artificial Insemination Projects Planning in The Arab Countries (AIPPAC'85), The Kingdom of Morocco, Rabat 1985; 1-29.

[13] Mashhour AFMF. Economics of Biotechnology for Dairy Cattle in Egyptian Agriculture: Genetic Investment, Doctoral Dissertation, Dept. Agri. Econ, Faculty of Agriculture, Zagazig University, Egypt 1995.

[14] Soliman I, Sadek MH. Impacts of Productive and Reproductive Performances on Investment Efficiency of Buffalo Enterprise in Egypt, proceedings of $7^{\text {th }}$ World Buffalo Congress. International Buffalo Federation: 212-217, Manila, Philippine 2004.

[15] Uwe G, Deryl N, Peter S. Investment Appraisal: Methods and Models. 2ed. Springer Texts in Business and Economics, Switzerland 2015.

[16] Barnard CS, Nix JS. Farm Planning and Control. Cambridge University Press, Cambridge. UK 1979. https://doi.org/10.1017/CBO9780511559914

[17] Brown, Maxwell L, Farm Budgets: From Farm Income Analysis to Agricultural Project Analysis, The Johns Hopkins University Press, Baltimore 1979.

[18] Gittinger JP. Economic analysis of Agricultural Projects.2nd Ed. John Hopkins University Press. Maryland, USA 1982.

[19] Blake RW, Shumway CR, Tomaszewski MA, Rickard GP, La Bore JM. Profit-maximizing dairy sire selection package. Journal of Agricultural and Applied Economics 1988; 20: 141144. https://doi.org/10.1017/S0081305200025723

[20] McMahon RT, Blake RW, Shumway CR, Leatham DJ, Tomaszewski MA, Butcher KR. Effects of planning horizon and conception rate on profit-maximizing selection of artificial insemination sires. Journal of Dairy Science 1985; 68: 22952302. https://doi.org/10.3168/jds.S0022-0302(85)81102-4

[21] Ibrahim MAR. Water buffalo for our next generation in Egypt and in the world. Scientific Papers. Anim Sci 2012; 55: 183192.

[22] Van Tassell CP, Jones LR, Elcker SW. Production Evaluation Techniques Based on Lactation Curves. Journal of Dairy Science 1995; 78(2). https://doi.org/10.3168/jds.S0022-0302(95)76655-3

[23] Pryce JE, Coffey MP, Simm G. The relationship between body condition score and reproductive performance. Journal of Dairy Science 2001; 84: 1508-1515. https://doi.org/10.3168/jds.S0022-0302(01)70184-1

[24] Soliman I. Buffalo Share in Small Farmer Welfare Under Intensive Agricultural System: The Case Study of Egypt. Proceeding of $10^{\text {th }}$ World Buffalo Congress \& $7^{\text {th }}$ Asian Buffalo Congress, 6-8 of May, Invited Papers, Phuket Thailand: 2013; Vol.1: pp. 132-140.

[25] Nigm AA, Abdel-Salam SAM, El-Sayed M, Sadek RR, Abdel Aziz AS. Preliminary results on use of the open nucleus breeding scheme for improving milk production of Egyptian buffalo. Egypt J Anim Prod 2005; 42: 1-9.

https://doi.org/10.21608/ejap.2005.92904

[26] CAPMAS, Central Agency of Public Mobilization and Statistics. Monthly Bulletin of Food Prices in Egypt, Nasr City, Cairo, Egypt 2017.

[27] FAOSTAT: FAO Statistics Division, FAOSTAT <fao.org> 2017.

[28] Soliman I, Abdul Zaher T. The Impact of Government Policies on Efficiency of Milk Production Systems in Egypt Proceedings Of $9^{\text {th }}$ International Congress of Statistics, Computer Sciences, Social and Demographic Research, P. 1-21, Scientific Computer Center, Ain Shams University, Cairo, Egypt 1984.

Received on 07-07-2020

Accepted on 28-07-2020

Published on 31-08-2020

\section{DOI: https://doi.org/10.6000/1927-520X.2020.09.19}

(C) 2020 Soliman and Bahgat; Licensee Lifescience Global.

This is an open access article licensed under the terms of the Creative Commons Attribution Non-Commercial License (http://creativecommons.org/licenses/by-nc/3.0/) which permits unrestricted, non-commercial use, distribution and reproduction in any medium, provided the work is properly cited. 